\title{
FBX031 wt Allele
}

National Cancer Institute

\section{Source}

National Cancer Institute. FBXO31 wt Allele. NCI Thesaurus. Code C153045.

Human FBXO31 wild-type allele is located in the vicinity of $16 \mathrm{q} 24.2$ and is approximately $65 \mathrm{~kb}$ in leng th. This allele, which encodes F-box only protein 31, is involved in G1 arrest and protein ubiquitination. Mutation of the gene is associated with autosomal recessive mental retardation type 45 . 